Historic, Archive Document

Do not assume content reflects current scientific knowledge, policies, or practices. 



\section{IRIS SEEDS}

\section{PLANT THEM EARLY, AS SOON AS RIPE.}

You will find the growing of Iris from seeds a most faccinatingmpasterme; true, exacting some patience, but rich in rewards. I have this year some magnificent new varieties blooming, one in particular was the cynosure of all eyes in my garden this Spring, another one is a much glorified Alcazar, much finer and larger than its parent-you can do the same. Most seeds come up the following Spring, some lie dormant for two years; they bloom the second year, some the third. The finer the seed parent, the more glorious the offspring is apt to be, works the same as with Delphiniums!

MIXED SEEDS from the best low priced varieties, per pkt. of 25 seeds, $25 \mathrm{c}$.

MIXED SEEDS from the best medium priced varieties, incluching such fine Irises ar Lord of June, Seminole, Dream, Alcazar, etc., per pkt. of 25 seeds $\$ 1.00$.

MIXED SEEDS from the finest garden varieties, such as Hermione, Madame Gaudichau, Mlle. Schwartz, Marsh Marigold, Shekinah, and others equally fine, per pkt. of 25 seeds, $\$ 2.00$.

STRAIGHT SEEDS from individual varieties, such as Ann Page, Morning Splendor, Phyllis Bliss, Robert W. Wallace, Emily Tenney (New-Pudor); 10c per seed, but not less than 3 seeds of any variety sold; you need that many seeds in order to se sure to get 1 or 2 plants.

ALWAYS NAME 2 SUBSTITUTES, as varieties ordered may not produce seedpods this season; this is impossible to tell at this time; last season hundreds of clumps of Lord of June did not produce a single seed pod.

IRIS, New California Bracteata.-In the type the flowers are yellow, beautifully netted with brown crimson veins, but seedlings produce a wide range of colour, including pinks and even reds. The seed offered was saved from the yellow-flowered variety. Per pkt. 25c.

IRIS, New California Tenax.-Flowers vary from deep claret to pale lavender or lilac, or pale grey with a beautiful network of silvery veins. The foliage is grassy and slender, but the plant is perfectly hardy. Per pkt. 25c.

By all means try some Californian Iris; they are most lovely, low growing subjects, with a wealth of flowers during May; with us the clumps stay green all winter.

SIEERIAN IRIS SEEDS, named or mixed, 25c per package.

JAPANESE IRIS SEEDS, from finest varieties, 25c per package; not ready untill September.

\section{AN EXCELLENT IRIS BULLETIN}

The U. S. Department of Agriculture at Washington, D. C., has issued an exceedingly interesting and well illustrated manual on Garden Irises, including chapters on Iris diseases and insect pests and remedies. You will find it of great value. Ask for Farmers' Bulletin No. 1406 and address your letter to the Superintendent of Documents, Government Printing Office, Washington, D. C., enclosing ten cents in coin, not stamps. Be sure and do it right.

\section{O. M. PUDOR \\ Iris Specialist}

Puyallup, Washington (In the Charmed Land) 
